\title{
IMPROVEMENT OF SOCIETY LEGAL CULTURE AS A BASIS FOR INCREASING TRANSPARENCY AND ACCOUNTABILITY OF THE JUDICIARY TO UKRAINIAN SOCIETY
}

\section{Vitalina Novoselova}

\section{INTRODUCTION}

The reform of the judicial power in Ukraine towards its harmonization with international standards of legal proceedings provides, among other things, for increasing its transparency, strengthening its accountability to civil society and restoring confidence in it. Over the past five years, civil society in Ukraine has enjoyed a significant increase in affecting the state power performance in Ukraine in general, and the judiciary in particular. The perception and understanding of the judicial reform processes by public largely depend on the legal culture of the Ukrainian society. That is the reason why improvement of legal culture in the Ukrainian society can become a reliable basis for increasing the judiciary transparency to public in Ukraine. The influence of civil society on increasing transparency of the judiciary to a large extent hinge on theoretical understanding of the problems that arise in this area.

It is also necessary to take account of the fact that in modern democratic states, the influence of civil society institutions on the judiciary has been widely viewed as a powerful tool for establishing justice. The expediency of increasing transparency and accountability of the judiciary to civil society is recognized in most modern civilized states that adhere to the rule of law. That is why a number of international and European non-governmental organizations which deal with the judiciary are making significant efforts to spread this practice. According to the Madrid Principles on the Relationship between the Media and Judicial Independence, "It is the function and right of the media to gather and convey information to the public and to comment on the administration of justice, including cases before, during and after trial, without violating the presumption of innocence. The right to comment on the administration of justice shall not be subject to any special restrictions" 1 .

\footnotetext{
${ }^{1}$ The Madrid Principles on the Relationship between the Media and Judicial Independence. Retrieved from: http://www.fair.org.ua/content/library_doc/Annex_43_Court_Communications_ Book_UKR.pdf.
} 
In addition, the Member States of the Organization for Security and Cooperation in Europe have agreed on the use of such a form of influence as monitoring of legal proceedings - presence of observers from other OSCE participating States and NGOs at trials in their states. Nowadays, this practice has become widespread $^{2}$. At the same time, growing demands for judiciary performance by civil society institutions require a high level of legal culture from the public, their understanding of the processes in the judicial system, directions of its reform and their compliance with international standards of justice.

Thus, the aim of our research is to study the ways of improving society legal culture as a basis for increasing transparency and accountability of the judiciary to the Ukrainian society.

Research methods. In order to achieve scientific objectivity of the results, a complex of philosophical, general scientific and special scientific approaches and cognition methods was applied. Among the methodological approaches which determine the worldview orientation, we applied a civilizational approach (in order to clarify the essence of legal culture and justice) and a dialectical approach (when analysing the development of the judicial system and legal culture). The general scientific methods of cognition used in our work include the following: a system method (when studying the structure of the judicial system, its links), a functional method (for revealing the process of the judicial power and legal culture functioning) and a statistical method (for characterizing quantitative indicators of the judiciary). Among the special scientific methods used there is a formal dogmatic method (for study of the Ukrainian and international legislation), a comparative legal method (in the context of comparing the legal principles of transparency and accountability in the Ukrainian and international legislation), legal determinism (in justifying the ways of improving the legal culture of the Ukrainian society), etc.

Degree of the problem scientific development. The analysis of scientific literature shows that the problem of increasing transparency and accountability of the judiciary is the subject of research by many domestic and foreign scientists. In modern foreign scientific literature, the problems of transparency of state power, the judiciary in particular, have been addressed by many scholars, namely: J. Martin, J. Keane, M. Weber, K. Popper, J. Stiglitz, J. Habermas, etc., who examined the judiciary in the context of information openness and responsibility of judicial authorities. Despite application of different approaches, the authors share a common view that

\footnotetext{
${ }^{2}$ Reanimation Package of Reforms (2018) The Report of the Centre of Policy and Legal Reform on the results of the Program of the Judicial Process Monitoring in Ukraine, [Online], available at: https://rpr.org.ua/news/zvit-tsppr-za-rezultatamy-prohramy-monitorynhu-sudovyhprotsesiv-v-ukrajini./
} 
transparency is seen as openness of the administration system of society for the public and a guaranteed right of access to information. In other words, transparency is always linked to access to information.

In the Ukrainian scientific literature, the problems of transparency have only been addressed in recent years, however, the issues of openness and transparency of the judiciary are more traditional. Among Ukrainian scientists, a significant contribution to the study of these issues was made by the following scholars: V. Bryntsev, I. Marochkin, M. Vilhushynskyi, V. Horodovenko, I. Hrytsenko, P. Kablak, L. Moskvych, I. Nazarov, S. Prylutskyi, O. Romaniuk, T. Strus-Dukhnych and others. Another particular group includes the writings of scholars who examined the impact of civil society on the judiciary performance, namely Yu. Bytiak and I. Iakoviuk, Yu. Kalynovskyi, O. Todyka, M. Tsymbaliuk, Yu. Loboda, L. Herasin, O. Danylian, O. Dzoban, V. Kolisnyk, S. Maksymov, L. Udovyka and others.

At the same time, the analysis showed that the issues of improving legal culture of civil society as a basis for increasing transparency of the judiciary to civil society in Ukraine remained outside the focus of scientists. It should also be noted that a large number of monographic studies and scientific articles are devoted to the legal culture of the Ukrainian society. The scientific achievements of these scholars lay the methodological basis for the study of legal culture and enable understanding of the legal culture of various entities and persons relevant to the activities related to increasing the transparency and accountability of the judiciary to civil society in Ukraine.

\section{Legal culture of Ukrainian society and its legal subjects in the context of impact on the judiciary}

The concept of "legal culture of the Ukrainian society" is extremely broad and requires some clarification. Without going into the discussion about scientific approaches to the concept of "legal culture", which is beyond the framework of our research, we should note that in the context of the given writing we understand legal culture of the Ukrainian society as a system of legal values and ideals that reflect the state (level) of legal development of society members, which manifests itself at three levels, namely intellectual, emotional-psychological and behavioral, ensures their lawful behavior and legal activity. At the intellectual level, the legal culture of society presupposes knowledge of law, legal awareness and knowledge of information. At the emotional-psychological level, the legal culture of the Ukrainian society is embodied in a positive attitude to law and belief of citizens in the necessity and social utility of laws, the rule of law and order. At the behavioral level, the legal culture of society means the ability to use legal means, that is laws and other legal instruments in practice, ability to comply with prohibitions, exercise rights, perform duties, protect rights, freedoms and legitimate interests. 
The legal culture of society means both knowledge and understanding of law as well as presence of its members' own legal judgments, legal thinking about law, its social value, and ultimately orientation not only to lawful behavior but also to legal activity. It is legal activity as one of the highest and most complicated manifestations of the legal culture of the Ukrainian society that is important for increasing transparency and accountability of the judiciary to the public. At the same time, it is legal activity that is based on the knowledge and understanding of the processes of the judiciary functioning. The public that do not have the appropriate level of legal knowledge are not able to objectively assess the content and essence of the processes occurring in the judiciary activity and reform in Ukraine. The influence of this kind of public on the activity of the judicial power is able not only distort the other society members' perception of the judicial power, damage its reputation, reduce confidence in it, but also hinder its proper activity and effective reform in establishing the European standards of judicial procedure.

The limited amount of work allows us to focus on the legal culture of some legal culture subjects of the Ukrainian society which do not represent subjects of the judiciary directly, but are related to its activities, affect shaping of public opinion, the level of trust, transparency and accountability of the judiciary to civil society. We are talking about participants in legal proceedings (plaintiffs, defendants, witnesses, defenders), jurors, people's assessors.

In the context of the above-said, the legal culture of society should be considered as a unity of the legal culture of the Ukrainian society subjects (individual legal culture). In this case, it is primarily represented by the legal culture of Ukrainian citizens, with some of them being participants in legal proceedings. Citizens who have applied to the court for protection of their rights, freedoms and legitimate interests at the initial level show a certain confidence in the judicial power and seek to legally protect their rights.

According to judicial statistics, 3.4 million cases and materials were submitted to local and appellate courts in 2017, 3.8 million cases - in 2018. The courts of first instance mostly deal with cases and materials of criminal and civil proceedings. The statistics data show a sharp rise in the number of criminal cases submitted for consideration to local ordinary courts ${ }^{3}$. During 2018, courts of first instance and appellate courts considered 3.6 million cases (in 2017, 3.3 million cases respectively) and materials (84.4\% of the total number of cases pending in the courts, in $2017-86 \%$ respectively $)^{4}$.

\footnotetext{
3 Judicial Power of Ukraine (2018) The Review of the Data on the State of Justice Administration in 2018. p. 2.

4 Judicial Power of Ukraine (2018) The Review of the Data on the State of Justice Administration in 2018. p. 4.
} 
The increase in the total number of applications from citizens to protect violated rights indicates, on the one hand, an increase in the number of human rights violations, and on the other hand, a certain confidence in the judiciary as an effective mechanism for protecting violated rights. At the same time, the legal culture of the citizens, who applied to the court, can be transformed during the legal proceedings and after their completion. Proper organization of all procedures, transparency and openness of legal proceedings, timely receipt of comprehensive information on issues, in particular with regard to court fees, necessary details, legal proceedings, cases, in which obtaining public information is requested (through the court web page) as well as free legal assistance if necessary, respect for citizens not only from judges but also from court employees have a positive affect on the person being stressed emotionally and psychologically.

It is also necessary to take into account the fact that general perception and attitude to the judicial system activities by legal proceedings participants indirectly affects a wider range of relatives and friends of these persons, promotes or, vice versa, reduces the level of confidence in the judicial power. Certainly, after a court decision (or sentence) is issued, in the vast majority of cases, there is a party that is not satisfied with it. This party has legal ways to appeal the decision by filing an application. However, if the judge violates the terms of case consideration, unreasonably delays the case or does not take measures to consider the appeal or case within the period established by law as well as in case of unreasonably long breaks in court sessions, problems with access to public information in court, inappropriate behavior of the judge or employees of the court, citizens' perception and attitude to the judicial system becomes negative. Unfortunately, we should admit that despite some positive developments in the judicial power in Ukraine concerning its transparency and accessibility, not only the Ukrainian society but also national and international experts recognize the presence of system problems in the judiciary, miscarriage of justice.

The above statement can be confirmed by the statistical data on the applications of Ukrainian citizens to the ECHR. Applications from Ukraine account for $12.9 \%$ of the entire workload of the ECHR. In total, approximately 56,350 applications were registered with the ECHR as of December 31, 2018. According to this indicator, only two COE Member States, Russia and Romania (11745 and 8503 applications, respectively) outpaced Ukraine. At the same time, in terms of the ratio of the number of cases and the number of population, Ukraine is not among the leaders and only occupies the 20th place among the COE Member States ${ }^{5}$. The largest

5 The European Truth. International Security and Eurointegration of Ukraine (2019). Available at: https://www.eurointegration.com.ua/news/2019/01/24/7091973/. 
number of applications to the ECHR is registered from citizens of five states (Russia, Romania, Ukraine, Turkey, Italy), which make up almost $70 \%$ of the ECHR cases.

The above arguments and statistical data in the context of the problem under study give rise to several important points: first, the legal culture of a significant part of the Ukrainian society subjects is at a level where a person shows legal activity to protect violated rights, addressing domestic and international courts. Second, it should also be taken into account that some citizens use pre-trial and out-of-court methods of resolving legal conflicts, which indicates appropriate legal culture and certain confidence in the effectiveness of legal means for protection of violated rights. Third, judicial decisions, rulings, sentences, transparency of court's activities and the quality of the process organization at all stages affect the legal culture of citizens, who are participants in legal proceedings, and can increase confidence in the judiciary or, conversely, reduce it significantly. Fourth, a certain portion of citizens, who are not satisfied with judicial decisions, seek to disseminate information, in their opinion, on improper judiciary activities or miscarriage of justice (e.g. in the media), are willing to obtain further information on the activities of separate courts and judges, have an opportunity to influence the activities of the judiciary. In some cases, such citizens are involved in activities of public organizations engaged in the judiciary activities. Fifth, communicative culture of judges, defense lawyers and prosecutors is important for citizens, who participate in legal proceedings. For many of such citizens, the adversarial nature of the trial has a special effect, which is able to replace the rational components of the process with the emotional components of the speech (e.g. the call for "fair trial without applying unfair laws"). Appeal to the feelings of the audience, creation of emotional tension during the trial, use of theatrical effects have impact on ordinary citizens lacking expertise and critical thinking, cause erroneous emotional assessments and conclusions. Relevant information, knowledge, and critical legal thinking can prevent shaping biased perception and making the assessment of the process and activities of the judiciary as a whole.

The influence of the above-mentioned category of citizens, namely the trial participants, on the judiciary towards increasing its transparency and accountability is exercised, in particular, by filing complaints against judges to the Supreme Council of Justice and initiating disciplinary action. Citizens should take into account the provisions of Article 106 of the Law of Ukraine "On the Judiciary and the Status of Judges", which provides for the procedure for disciplinary proceedings in respect of a judge ${ }^{6}$. In addition, a citizen has

\footnotetext{
${ }^{6}$ The Law of Ukraine (Jul. 7, 2010) No. 2453-VI "On the Judiciary and the Status of Judges", Vidomosti Verkhovnoi Rady Ukrainy [The Official Bulletin of the Verkhovna Rada of Ukraine], 2016, No 31, Art. 545.
} 
the right to file a claim to the court for delivery of a knowingly unfair sentence, judgment, ruling or order by a judge (or judges) (Article 375 of the Criminal Code of Ukraine) ${ }^{7}$.

Participants in the legal proceedings also have other legal means of influencing the judiciary in order to increase its transparency and accountability. One of the levers of influence to increase the judiciary transparency can also be considered a citizen's request for public information, followed by disclosure of information in the media and drawing public attention to activities or behavior of a judge. However, the influence of individual citizens on the judicial power activity in Ukraine with regard to increasing its transparency and accountability can be considered significant on condition. Only under the condition of access and, at the same time, the interest of the media, an ordinary citizen can draw a wide response to a certain case. The legal activity of such a citizen, his knowledge, perseverance, integrity, a desire to use all available legal ways to protect violated rights and influence the judicial power (judge) in order to increase its transparency and accountability become extremely important. In addition, this activity requires significant psychological, physical, material and time resources. That is why the activities of public organizations' members, especially those of human rights organizations, are more effective in influencing the judiciary.

In the context of the research subject, special attention should be paid to the legal culture of jurors and people's assessors, who have a significant impact on the activities of the judiciary in general, increasing its transparency and accountability in particular. The introduction of the Institution of Jury Trial in Ukraine as one of the assets of legal development is intended to become an effective form of implementation of democracy in legal proceedings, a reliable basis for reform of the judiciary in accordance with the international and European legal principles and standards and a source of powerful development of the Ukrainian legal system.

Prior to investigating the legal culture of jurors, we should focus on defining their status. According to the Law of Ukraine "On the Judiciary and the Status of Judges", Article 58 "The Status of a People's Assessor and a Juror", "1. A people's assessor shall be a citizen of Ukraine who in situations prescribed by the procedural law shall adjudicate cases, as a member of a court panel, together with a judge, providing direct participation of the people in the administration of justice as required by the Constitution of Ukraine. When hearing and adjudicating cases, people's assessors shall exercise powers of a judge. 2. A juror shall be a citizen of Ukraine who in situations

\footnotetext{
${ }^{7}$ The Criminal Code of Ukraine (Apr. 05,2001) No. 2341-III, Vidomosti Verkhovnoi Rady Ukrainy [The Official Bulletin of the Verkhovna Rada of Ukraine], 2001, No 25-26, Art. 131.
} 
prescribed by the procedural law shall be engaged in administration of justice, providing direct participation of the people in the administration of justice as required by the Constitution of Ukraine"

The current legislation of Ukraine establishes requirements for a people's assessor and juror, namely: a people's assessor or juror must be a citizen of Ukraine who has reached the age of thirty and permanently resides in the territory covered by the jurisdiction of the respective court.

In Ukraine, a jury trial can be used for certain categories of civil and criminal proceedings. Article 59 "List of People's Assessors" and Article 60 "List of Jurors" of the Law of Ukraine "On the Judiciary and the Status of Judges" say that the lists of jurors shall be formed and approved by a decision of the respective local council for a two-year term upon the proposal of the territorial department of the State Judicial Administration. The list consists of citizens who permanently reside in the territory covered by the jurisdiction of the relevant court, meet the requirements specified below and have given consent to be jurors. That is, citizens can be jurors only on a voluntary basis.

The list of requirements for jurors is limited by the age criterion (from 30 to 65 years old), the criteria of territorial certainty and settlement, legal capacity, absense of criminal record, the command of the state language and a certain category of persons. The Law does not define any special requirements for moral or legal qualities of the citizens. According to Article 61 "The Requirements for a People's Assessor and Juror", "Citizens shall not be included in a list of people's assessors or a list of jurors if they: 1) were found by court to have limited legal capacity or legal incapacity; 2) are suffering from chronic mental or other diseases which prevent them from performing the duties of a people's assessor, juror; 3 ) have an outstanding or unquashed conviction; 4) are people's deputies of Ukraine (MPs), members of the Cabinet of Ministers of Ukraine, judges, prosecutors, law enforcement officers, military personnel, court staff, other public servants, officials of local governments, lawyers, notaries, members of the High Qualifications Commission of Judges of Ukraine, Supreme Council of Justice; 5) have been subject to administrative liability for committing a corruption offense within the year; 6) have reached the age of 65 ; 7) have no command of the state language" . Therefore, it should be concluded that any person who meets the established requirements can perform the functions of a juror. We should also

\footnotetext{
${ }^{8}$ The Law of Ukraine (Jul.7, 2010) No. 2453-VI "On the Judiciary and the Status of Judges", Vidomosti Verkhovnoi Rady Ukrainy [The Official Bulletin of the Verkhovna Rada of Ukraine], 2016, No 31, Art. 545.

${ }^{9}$ The Law of Ukraine (Jul.7, 2010) No. 2453-VI "On the Judiciary and the Status of Judges", Vidomosti Verkhovnoi Rady Ukrainy [The Official Bulletin of the Verkhovna Rada of Ukraine], 2016, No 31, Art. 545.
} 
pay attention to the fact that there is no requirement for jurors to have a full secondary or higher education.

The analysis shows that the current legislation of Ukraine does not establish moral or educational requirements for jurors involved in the administration of justice. The existing jury selection mechanism does not contain separate requirements for moral qualities, a cultural or educational background. It should be noted that the above criteria were taken into account in the mechanism that existed in the Soviet times and involved discussion of candidates at meetings of the labor collective, election of persons from among them who meet certain moral criteria and enjoy trust of the collective. Moreover, in legal science, scolars constantly emphasize on the importance of moral requirements for people's assessors, importance of high moral and human qualities of an assessor, which give him not only the legal right but also the moral one to judge other people. Among the personality traits contraindicated for judicial activity, scientists noted the following ones: prejudice, disrespect for people, rudeness, irascibility, arrogance, etc. ${ }^{10}$ First of all, a people's assessor must have such moral qualities as justice, responsibility for the fate of people, adherence to principles, honesty and consciousness. At the same time, such negative personal qualities as irresponsibility, injustice, unprincipledness, cruelty and propensity for deception are among the most unacceptable for people's assessors.

Therefore, the determinative qualities, which a juror, a people's assessor should have, are his ability and skills, common sense and some life experience. Secondary education, high moral and volitional qualities as well as legal activity were not among the determinative criteria for making a list of jurors and people's assessors. Hence, we can conclude that the legal culture of jurors and people's assessors when making lists can be identified as the legal culture of ordinary citizens, who form the legal culture of society, in the structure of which the emotional, psychological and behavioral levels, but not intellectual ones, prevail.

The peculiar feature of jurors and people's assessors' legal culture lies in the fact that it occupies a special place among other varieties and forms of legal culture. On the one hand, it is the legal culture of a person, whose legal position is aimed at strengthening the rule of law and order by performing various types of social activities. On the other hand, taking into account the legal activity of jurors and people's assessors as participants in the administration of justice, their legal culture, in its essence and content, is close

\footnotetext{
${ }^{10}$ Groshevoy Yu. M. (1975) Problemy formirovaniya sudeyskogo ubezhdeniya v ugolovnom sudoproizvodstve [The problems of shaping judicatory convictions in criminal proceedings]. Kharkiv: Vyshcha shkola.
} 
to the professional legal culture of a lawyer. That is why the problem of improving the legal culture of jurors and people's assessors is of great importance.

\section{Directions for improvement of society legal culture as a basis for increasing transparency of the judiciary to the Ukrainian society}

When justifying the directions for improving society legal culture as a basis for increasing transparency of the judiciary to the Ukrainian society, it is necessary to take into account several aspects, among them, in particular, are the following: first, the levels and structure of the legal culture of the subjects who exercise influence; second, the legal principles of transparency and accountability of the judiciary in Ukraine.

As it was noted above, legal culture exists at the intellectual, emotional, psychological and behavioral levels. The intellectual level of legal culture implies knowledge of law, legal awareness and knowledge of information. It is at this level that knowledge of law and understanding of the fact that the impact on the judiciary has clear legal boundaries established at the legislative level is extremely important. The legal framework for transparency and accountability of the judiciary in Ukraine is provided for by the Constitution of Ukraine, in particular Articles 32, 34, 129 ${ }^{11}$. Article 129 of the Constitution of Ukraine is fundamental, as, according to it, in the administration of justice, judges are independent and subject only to the law; the main principles of judicial proceedings are, in particular, openness of a trial and its complete recording by technical means.

The Laws of Ukraine "On Access to Public Information"12 and "On Access to Court Decisions"13 also apply to the context of directions and activity forms of civil society institutions in increasing transparency and accountability of the judiciary. Thus, Article 3 of the Law of Ukraine "On Access to Public Information"provides for the guarantees of observance of the right to access to public information, namely: transparency and openness of the activities of government agencies; free receipt, distribution and any other

${ }^{11}$ The Constitution of Ukraine (June 28, 1996), Vidomosti Verkhovnoi Rady Ukrainy [The Official Bulletin of the Verkhovna Rada of Ukraine], 1996, No 30, Art. 141, (as amended by the Law of Ukraine "On Amendments to the Constitution of Ukraine (concerning justice)" (June 2, 2016), Vidomosti Verkhovnoi Rady Ukrainy [The Official Bulletin of the Verkhovna Rada of Ukraine], 2016, No 51, p. 8, Art. 1799).

${ }^{12}$ The Law of Ukraine (Jan. 13, 2011) No. 2939-VI “On Access to Public Information”, Vidomosti Verkhovnoi Rady Ukrainy [The Official Bulletin of the Verkhovna Rada of Ukraine], 2011, No 32, Art. 314.

${ }^{13}$ The Law of Ukraine (Dec. 22, 2005) No. 3262-IV "On Access to Court Decisions", Vidomosti Verkhovnoi Rady Ukrainy [The Official Bulletin of the Verkhovna Rada of Ukraine], 2006, No 15, Art. 128. 
use of information that was provided or made public in accordance with this Law, except for restrictions established by the law; equality, regardless of the race, political, religious and other beliefs, gender, ethnic and social origin, property status, place of residence, language or other characteristics ${ }^{14}$.

The rules on the publicity of legal procedure are also contained in the procedural legislation: the Articles of the Civil Code of Ukraine (Article 296 The Right to Use the Name, Article 302 The Right to Information) ${ }^{15}$; the Civil Procedure Code of Ukraine (Article 7 Publicity of the Trial, Article 8 Transparency of Information on the Trial, Article 14 The Unified Judicial Information and Telecommunication System ${ }^{16}$; the Code of Administrative Procedure of Ukraine (Article 10 Publicity of the Administrative Procedure, Article 11 Transparency of Information on the Trial) ${ }^{17}$; the Economic Procedure Code of Ukraine (Article 8 Publicity of the Economic Procedure, Article 11 Transparency of Information on the Trial, Article 6 The Unified Judicial Information and Telecommunication System) ${ }^{18}$; the Criminal Procedure Code of Ukraine (Article 27 Publicity and Openness of Court Proceedings and Complete Recording Using Technical Means of a Court Session and Legal Proceedings) ${ }^{19}$.

Analyzing and summarizing their contents, we can distinguish the three main aspects of transparency: 1) the duty of the court to ensure publicitytransparency of court proceedings, which is implemented by placing ads on the time, day and place of the hearing, allowing the parties to familiarise with the materials of the case; 2) the right of parties to a public hearing of the case, which is their right to an open trial, awareness about the contents of the claims and objections of the parties, acquaintance with the case materials, the right to be heard at the trial, etc.; 3) the right of those who wish

14 The Law of Ukraine (Jan. 13, 2011) No. 2939-VI "On Access to Public Information", Vidomosti Verkhovnoi Rady Ukrainy [The Official Bulletin of the Verkhovna Rada of Ukraine], 2011, No 32, Art. 314.

${ }^{15}$ The Civil Code of Ukraine (Jan. 16, 2003) No. 435-IV, Vidomosti Verkhovnoi Rady Ukrainy [The Official Bulletin of the Verkhovna Rada of Ukraine], 2003, No. 40-44, Art. 356.

${ }^{16}$ The Civil Procedure Code of Ukraine (Mar. 18, 2004) No. 1618-IV, Vidomosti Verkhovnoi Rady Ukrainy [The Official Bulletin of the Verkhovna Rada of Ukraine], 2004, No. 40-41, No 42, Art. 492.

${ }^{17}$ The Code of Administrative Procedure of Ukraine (Jul. 6, 2005) No. 2747-IV, Vidomosti Verkhovnoi Rady Ukrainy [The Official Bulletin of the Verkhovna Rada of Ukraine], 2005, No 35-36, No 37, Art. 446.

18 The Economic Procedure Code of Ukraine (Nov. 6, 1991) No. 1798-XII, Vidomosti Verkhovnoi Rady Ukrainy [The Official Bulletin of the Verkhovna Rada of Ukraine], 1992, No 6, Art. 56.

19 The Criminal Procedure Code of Ukraine (Jul. 7, 2013) No.4651-VI, Vidomosti Verkhovnoi Rady Ukrainy [The Official Bulletin of the Verkhovna Rada of Ukraine], 2013, No 9-10, 11-12, No 13, Art. 88. 
to attend open court hearings, including representatives of the mass media, to disseminate and receive information about the court's activities. At the same time, it is necessary to distinguish the following types of trial transparency: 1) publicity for the parties (applies to persons, who are directly involved in the trial, the decision or sentence on which concerns or may concern their rights and obligations); 2) general publicity, which, in turn, is divided into certain types, the classification of which depends on the nature of the interest of entities and persons in obtaining information on the case; this is openness of court sessions: a) for persons who have a professional interest (representatives of the media, lawyers, law students, etc.); b) for persons who have a personal interest (relatives, close people, acquaintances of the parties to the process); c) for all disinterested persons (the public).

According to the current legislation, court decisions, court sessions and information on the cases considered by the court are open, except for cases specified by the legislation. No one shall be restricted in the right to obtain from the court information in the oral or written form on the results of his/her case consideration. Any person has the right to free access to a court decision in accordance with the procedure established by the legislation. Cases are considered in courts in public, except for cases established by law. Any person shall have the right to attend an open court session.

The legal grounds for publicity, transparency and accountability of the judiciary are also established by the provisions of the Law of Ukraine "On the Judiciary and the Status of Judges". In particular, Article 11 "Publicity and Transparency of Court Proceedings" states that court decisions, court sessions and hearing of cases in courts shall be open, except for cases specified by the procedural law. No one shall be restricted in the right to obtain from the court written or verbal information about the results of consideration of his/her case. Any person shall have the right to free access to a court decision in the manner prescribed by law ${ }^{20}$.

For the public, it is important to obtain information about the court as a public authority, judges, specific legal proceedings as well as to have access to court decisions. According to its content, information which can be obtained by citizens from the court, is grouped as follows: 1) information obtained by the court in the course of legal proceedings, and 2) information available to the court but not related to the administration of justice. An important element of judicial transparency is ensuring availability of judicial proceedings' results - court decisions. In Ukraine, in order to resolve the issue

20 The Law of Ukraine (Jul.7, 2010) No. 2453-VI "On the Judiciary and the Status of Judges", Vidomosti Verkhovnoi Rady Ukrainy [The Official Bulletin of the Verkhovna Rada of Ukraine], 2016, No 31, Art. 545. 
of ensuring access of individuals and legal entities to decisions of courts of all levels, the Law of Ukraine "On Access to Court Decisions" of December 22, 2005 (as amended) $^{21}$ is applied. The Law establishes the order of access to court decisions with the view of ensuring openness of activities of courts of general jurisdiction, predictability of court decisions and promotion of identical application of the legislation. The main issues regulated by the Law will be considered below.

Under the given Law, the Unified State Register of Court Decisions was created, which is an automated system for collecting, storing, protecting, recording, searching and providing electronic copies of judicial decisions. In order to increase transparency of the judiciary and level of public confidence in the judiciary, first and foremost, it is essential to ensure proper functioning of public access to court decisions. Users can access electronic copies of court decisions for free around the clock via the official web portal of the State Judicial Administration "The Judicial Power of Ukraine" 22 . Each individual or legal entity shall have general access to court decisions entered in the Register. At the same time, the Law contains provisions aimed at protecting personal information.

In addition to the general access to court decisions via the Register, it is also possible for persons concerned to have access to court decisions by contacting the office of the respective court. Thus, according to Article 9 of the Law of Ukraine "On Access to Court Decisions", a person who is not a party to the case, provided that the court decision concerns his/her rights, freedoms, interests or duties directly, can apply to the office of the respective court with a written application about the following: 1) granting an opportunity to familiarise with a judicial decision; 2) granting an opportunity to make copies of a court decision in the court building with the aid of own technical means; 3) making copies of a judicial decision by the judicial bodies $^{23}$.

There are a number of reasons for a person to be denied access to a court decision: 1) appeal to the court by a person who does not have procedural active legal capacity or a person on behalf of an interested person in the absence of the appropriate authority; 2) the case materials have been transferred to another court or stored in a state archive institution; 3 ) the court

${ }^{21}$ The Law of Ukraine (Dec. 22, 2005) No. 3262-IV "On Access to Court Decisions", Vidomosti Verkhovnoi Rady Ukrainy [The Official Bulletin of the Verkhovna Rada of Ukraine], 2006, No 15, Art. 128.

${ }^{22}$ The Judicial Power of Ukraine (2020). Available at: www.court.gov.ua.

${ }^{23}$ The Law of Ukraine (Dec. 22, 2005) No. 3262-IV "On Access to Court Decisions", Vidomosti Verkhovnoi Rady Ukrainy [The Official Bulletin of the Verkhovna Rada of Ukraine], 2006, No 15, Art. 128. 
decision does not directly affect the rights, freedoms, interests or obligations of this person. This list is not comprehensive.

Along with obtaining a court decision from the Register and directly from the court, court decisions can be published in printed matters and distributed in an electronic form. The law provides for official and unofficial publications of court decisions. Texts of court decisions are published in various collections, periodicals of courts, namely, in "The Court Appeal", "The Bulletin of Economic Justice", "The Bulletin of the Supreme Court of Ukraine", "The Decisions of the Supreme Court of Ukraine", "The Bulletin of the Constitutional Court of Ukraine", "The Judicial System and Legal Proceedings in Ukraine" as well as in journals and newspapers, in particular, in "The Legal Bulletin of Ukraine", "Yurydychna Gazeta", "Law\&Business", and others.

Openness, transparency and accountability of the judiciary are enshrined in a number of international and European legal acts. The rules established by the Council of Europe also define the restrictions on recording information in court proceedings by technical means (except for that carried out by the court). In particular, Recommendation Rec (2003) 13 of the Committee of Ministers to Member States on the provision of information through the media in relation to criminal proceedings says, "Live reporting or recordings by the media in court rooms should not be possible unless and as far as expressly permitted by law or the competent judicial authorities. Such reporting should be authorised only where it does not bear a serious risk of undue influence on victims, witnesses, parties to criminal proceedings, juries or judges". That is, the recording is prohibited, first of all, in order not to affect adversely the participants of the trial $^{24}$.

The legal way of influencing the judicial power is a citizen's claim to take disciplinary action against a judge. Citizens must take into account the provisions of Article 106 of the Law of Ukraine "On the Judiciary and the Status of Judges", which determine the procedure for disciplinary action against judges. Thus, the Law of Ukraine "On the Judiciary and the Status of Judges" defines disciplinary liability of a judge. According to Article 106 of the given Law, disciplinary proceedings against a judge may be initiated on the following grounds, among them, in particular, there are intentional actions or those resulting from negligence: a) unlawful denying a person's access to justice or other material violation of procedural law; violation of the principles of transparency and openness of legal proceedings; violation of the principles of equality of the legal proceedings participants before the law and court,

\footnotetext{
${ }^{24}$ Recommendation NR (2003) 13 of the Committee of Ministers to Member States, (Jul. 10, 2003) "On the provision of information through the media in relation to criminal proceedings".
} 
competitiveness of parties; failure to provide the accused with the right to defense, infringing upon the rights of other participants of legal proceedings; violation of the rules regarding recusal (self-recusal); unjustified delay or failure by a judge to consider an application, complaint or case within the time limit established by law; a judge's conduct that discredits the title of judge or undermines the authority of justice, in particular in matters of morality, honesty, integrity, compliance with the judge's lifestyle status, compliance with other standards of judicial ethics and the standards of conduct that ensure public confidence in the court; disrespect for other judges, lawyers, experts, witnesses or other participants of the proceedings; intentional violation or violation due to gross negligence by a judge who participated in making a judicial decision, of human rights and fundamental freedoms or other serious violation of law, which resulted in significant negative consequences; disclosure by a judge of the secrets protected by law; interference with the administration of justice by other judges; failure to submit or untimely submission for publication of the authorised person's declaration; declaration of false information; a judge's non-virtouos conduct; establishment of the inconsistencies of a judge's standard of living to the incomes declared; nonconfirmation by a judge of the legality of goods origin, etc. Judges may be subjected to disciplinary penalties, namely: a warning, reprimand, severe reprimand, suspension of a judge from the administration of justice, transfer of a judge to the court of a lower level and dismissal of a judge from office ${ }^{25}$.

Thus, citizens have certain legal means of affecting the judiciary in the context of increasing its transparency and accountability to society. At the same time, they are limited by the fundamental principles of the judiciary the principle of independence and autonomy, legal pemises for transparency and publicity.

Special attention should be paid to the question of how people's assessors and jurors influence the judiciary in the context of increasing its transparency and accountability, and therefore improving their legal culture. The peculiarity of the legal culture of jurors and people's assessors is that it occupies a special place among other varieties and forms of legal culture. On the one hand, it is the legal culture of a person, who, by performing various types of public activities, uses his legal stand to strengthen the rule of law and order, transparency and accountability of the judiciary to the Ukrainian society. On the other hand, taking into account the legal activity of jurors and people's assessors as participants in the administration of justice, their legal culture in its essence and content is close to the professional legal culture of a lawyer.

\footnotetext{
${ }^{25}$ The Law of Ukraine (Jul.7, 2010) "On the Judiciary and the Status of Judges", Vidomosti Verkhovnoi Rady Ukrainy [The Official Bulletin of the Verkhovna Rada of Ukraine], 2016, No 31, Art. 545.
} 
We believe that the legal culture of jurors and people's assessors is largely determined by their legal status. According to S. Ivanytskyi, "a complex, dualistic nature of the legal status of non-professional judges, who, on the one hand, are representatives of the people, and on the other hand, are members of a collective judicial body of state power, is derived from the functions and competence of the court. The binary position of a people's assessor in court proceedings provides for accumulation in his activities of state-assigned powers through his emotional-volitional and other personal qualities, which during the administration of justice are closely and inextricably related to the legal opportunities provided to him. Thus, the creative, interpretative component of work of a people's assessor, who does not have a special (psychological, etc) training for judicial activity, requires that his inherent human qualities should meet certain regulatory requirements, which ensure successful performance of his duties in the administration of justice" ${ }^{26}$.

Therefore, there arises a question about the presence of common and distinctive features in the legal culture of jurors as ordinary citizens of society and persons involved in legal activities (professional activity of a judge). The common features in the content of the legal culture of professional lawyers and legal culture of jurors are as follows: legal awareness and legal thinking; belief in the necessity and social utility of laws and regulations; lawful behavior; outcomes of lawful behavior and legal thinking. At the same time, the peculiarity of the legal culture of jurors and people's assessors consists in a certain level of development of the above-mentioned components of legal culture. Their level of legal activity is revealed in the readiness for initiatives in the legal area based on respect for law, conviction of necessity and fairness of legal norms, their voluntary implementation, proper knowledge of law, purposeful, positive, socially useful activity of the person. Of course, the legal culture of an individual juror is formed depending on the degree of assimilation and manifestation of the values of the society legal culture, specifics of professional activity, individual uniqueness of each person's creativity, life experience, etc. The cultural style of lawful behavior and constant compliance with the legal principles in lawful behavior are common features of jurors' legal culture.

In contrast to professional legal culture, whose bearers possess a high degree of knowledge and understanding of legal phenomena in the relevant areas of professional activity, critical and creative understanding of legal

${ }^{26}$ Moskvych L.M., Ivanytskyi S.O., Rusanova T.O. (2009) Pravovyi status nosiiv sudovoi vlady v Ukraini (profesiini suddi, narodni zasidateli, sud prysiazhnykh) [The legal status of judicial authorities in Ukraine (professional judges, people's assessors, jury). In Marochkin I.Ye. (ed.). Kharkiv: Finy (in Ukrainian). 
norms, laws, legal phenomena in terms of their humanistic, democratic and moral content, the legal culture of jurors and people's assessors is characterized by a lower level of knowledge. The ability to apply legal instruments - laws and other legal acts, use all the achievements of legal science and practice when making a particular court decision is also different for two groups. However, critical and creative interpretations of legal norms by jurors tend to be in line with those by professional lawyers, and in combination with knowledge in other fields, areas of science, life experience, high legal activity of jurors and people's assessors, they can ultimately contribute to making a weighted and grounded decision (verdict).

From the above stated it is obvious that in the legal culture of jurors and people's assessors, an essential role is played by legal consciousness in general and its evaluation function in particular. Performance of the evaluation function of legal awareness is based on the presence of certain legal knowledge, that is, the rational component of legal awareness, which is mainly the result of life experience, mental, intellectual activity of the person.

The structure of the legal consciousness and legal culture of jurors and people's assessors includes legal knowledge, legal values, legal concepts, legal conceptions of legal rights and obligations, legality, law and order, regulations, justice, legal feelings, etc. The formation of legal knowledge, values and conceptions of jurors takes place gradually and results from numerous cases of legal assessment as well as rational and emotional justification of positive significance of certain legal phenomena. It should be noted that legal assessment is organically linked to cognitive and emotional blocks of legal consciousness and revealed in appropriate rational-emotional forms.

Along with the legal consciousness as a rational component, an important role in the legal culture of jurors and people's assessors is played by the emotional-irrational component of legal consciousness, which exists in the form of a system of emotions, moods, experiences, feelings, etc. It serves as a certain basis for the rational and ideological area of legal awareness. Highlighting the legal culture of a society, a professional group or an individual, we should remember that in real life they are closely interrelated and correlate as the general, particular and individual. Legal culture as a social and legal phenomenon is single, and it is embodied in the legal culture of various groups, communities and individuals.

\section{CONCLUSIONS}

Based on our research, the following conclusions and generalizations can be made. Ukraine's entry into the European legal space is closely linked to the improvement of the Ukrainian society legal culture. Only on condition that the 
values of democracy, justice, responsibility and their protection are perceived and assimilated, the protection of human and civil rights and freedoms is effective. In this context, the issue of increasing the transparency and accountability of the judiciary to the Ukrainian society as one of the international standards of legal proceedings is of great importance. Achievement of this goal is impossible without improvement of society legal culture. Among a large number of society's legal culture subjects, special attention should be paid to the legal culture of the subjects related to the activities of the judiciary and influencing towards increasing its transparency and accountability.

Given the limited scope of work, the research subject was the legal culture of the Ukrainian society's members, who are not the judicial power subjects directly, but are related to its activities, namely: participants in trials (plaintiffs, defendants, witnesses, defenders), jurors and people's assessors. The legal culture of these subjects manifests itself at three levels: intellectual, emotional-psychological and behavioral, although to a different extent. The levels of legal culture and their significance for each group of subjects determine the direction and content of the improvement.

The analysis showed that the improvement of these subjects' legal culture involves not only assimilation of legal information, but also formation of legal knowledge, skills and critical legal thinking. At the stage of participation in the judicial process, it is important to be aware of the judiciary and its system activities and be able to obtain necessary information about the case. A higher level of legal culture is necessary when a person is legally active and seeks to influence the judiciary activities in order to increase its transparency and accountability by submitting a citizen's request for public information or filing a complaint against a judge. Involvement of citizens in the administration of justice and empowerment them as judges in case consideration and adjudgement involves intensive intellectual and emotional-volitional activities. The reasonableness and validity of the conclusions to be made by jurors and people's assessors depend primarily on the knowledge acquired empirically, life experience, ability to make assessments, emotional stability and balance. Given this, the problem of increasing the general level of the Ukrainian society legal culture, improving and optimizing the areas of legal attitude development and legal education, conducting trainings, lectures, and providing appropriate conditions for the duties performance by jurors and people's assessors during consideration of cases and making decisions is relevant.

Another important direction of improving the Ukrainian society legal culture in the context of increasing the transparency and accountability of the judiciary is educational work which aims to mobilize the public for solution of common problems or carry out trainings for specific target audiences, namely: 
conferences, seminars, round tables concerning certain issues; press conferences, programs on relevant topics in the mass media; analytical journalism; trainings on specific issues of an applied nature (e.g. establishment and operation of centres dealing with the issues of trial, ejustice, etc.); preparation and distribution of brochures among the citizens and other mechanisms for defending their rights in court. Along with the appropriate knowledge, organizational and communication skills, this kind of legal educational work requires its organizers to have a common active legal and civil position.

We should emphasize that optimization of the directions and forms of civil society institutions' activity in increasing the transparency and accountability of the judiciary to society is also inseparably linked with the activities of the judicial authorities, their interaction with civil society institutions. Creation of an electronic database of the Supreme Court positions with a convenient search engine, a new structured form of judicial decision, online broadcasting of all open court sessions, full communication with the parties via the Internet (electronic court), regular public reports to the public should become the essential directions for improvement of citizens' legal culture.

\section{SUMMARY}

The article deals with the issue of the ways of improving society legal culture as a basis for increasing transparency and accountability of the judiciary to the Ukrainian society.

The entry of Ukraine into the European legal space is closely linked to the improvement of the Ukrainian society legal culture. Only on condition that the values of democracy, justice, responsibility and their protection are perceived and assimilated, the protection of human and civil rights and freedoms is effective. In this context, the issue of increasing the transparency and accountability of the judiciary to the Ukrainian society as one of the international standards of legal proceedings is of great importance.

The subject of our research is the legal culture of those Ukrainian society's members, who are not the judicial power subjects directly, but are related to its activities, namely: participants in trials (plaintiffs, defendants, witnesses and defenders), jurors and people's assessors. The legal culture of these subjects is revealed at three levels: intellectual, emotional-psychological and behavioral, although to a different extent. The levels of legal culture and their significance for each group of subjects determine the direction and content of the improvement.

The article proves the improvement of these subjects' legal culture involves not only assimilation of legal information, but also formation of legal knowledge, skills and critical legal thinking. At the stage of participation in 
the judicial process, it is important to be aware of the judiciary and its system activities and be able to obtain necessary information about the case. A higher level of legal culture is necessary when a person is legally active and seeks to influence the judiciary activities in order to increase its transparency and accountability by submitting a citizen's request for public information or filing a complaint against a judge. Involvement of citizens in the administration of justice and empowerment them as judges in case consideration and adjudgement involves intensive intellectual and emotionalvolitional activities.

Educational work which aims to mobilize the public for solution of common problems or carry out trainings for specific target audiences represents an important direction of improving the Ukrainian society legal culture in the context of increasing the transparency and accountability of the judiciary.

The author notes that optimization of the directions and forms of civil society institutions' activity in increasing the transparency and accountability of the judiciary to society is also inseparably related to the activities of the judicial authorities, their interaction with civil society institutions.

\section{REFERENCES}

1. The Madrid Principles on the Relationship between the Media and Judicial Independence. Retrieved from: http://www.fair.org.ua/content/ library_doc/Annex_43_Court_Communications_Book_UKR.pdf.

(in Ukrainian) (accessed 20 November 2019).

2. Reanimation Package of Reforms (2018) The Report of the Centre of Policy and Legal Reform on the results of the Program of the Judicial Process Monitoring in Ukraine, [Online], available at: https://rpr.org.ua/news/zvittsppr-za-rezultatamy-prohramy-monitorynhu-sudovyh-protsesiv-v-ukrajini./ (in Ukrainian) (accessed 16 December 2019).

3. Judicial Power of Ukraine (2018) The Review of the Data on the State of Justice Administration in 2018. p. 2. Retrieved from: https://court.gov.ua/ userfiles/media/media/ogl_2018.pdf (in Ukrainian) (accessed 20 December 2019).

4. Judicial Power of Ukraine (2018) The Review of the Data on the State of Justice Administration in 2018. p. 4. Retrieved from: https://court.gov.ua/ userfiles/media/media/ogl_2018.pdf (in Ukrainian) (accessed 20 December 2019).

5. The European Truth. International Security and Eurointegration of Ukraine (2019). Available at: https://www.eurointegration.com.ua/ news/2019/01/24/7091973/ (in Ukrainian) (accessed 21 December 2019).

6. The Law of Ukraine (Jul.7, 2010) No. 2453-VI "On the Judiciary and the Status of Judges", Vidomosti Verkhovnoi Rady Ukrainy [The Official 
Bulletin of the Verkhovna Rada of Ukraine], 2016, No 31, Art. 545, [Online], available at: https://zakon.rada.gov.ua/laws/show/1402-19 (in Ukrainian) (accessed 10 January 2020).

7. The Criminal Code of Ukraine (Apr. 05,2001) No. 2341-III, Vidomosti Verkhovnoi Rady Ukrainy [The Official Bulletin of the Verkhovna Rada of Ukraine], 2001, No 25-26, Art. 131, [Online], available at: https://zakon.rada.gov.ua/laws/show/2341-14 in Ukrainian) (accessed 10 January 2020).

8. The Law of Ukraine (Jul.7, 2010) No. 2453-VI "On the Judiciary and the Status of Judges", Vidomosti Verkhovnoi Rady Ukrainy [The Official Bulletin of the Verkhovna Rada of Ukraine], 2016, No 31, Art. 545, [Online], available at: https://zakon.rada.gov.ua/laws/show/1402-19 (in Ukrainian) (accessed 10 January 2020).

9. The Law of Ukraine (Jul.7, 2010) No. 2453-VI "On the Judiciary and the Status of Judges", Vidomosti Verkhovnoi Rady Ukrainy [The Official Bulletin of the Verkhovna Rada of Ukraine], 2016, No 31, Art. 545, [Online], available at: https://zakon.rada.gov.ua/laws/show/1402-19 (in Ukrainian) (accessed 10 January 2020).

10. Groshevoy Yu. M. (1975) Problemy formirovaniya sudeyskogo ubezhdeniya $v$ ugolovnom sudoproizvodstve [The problems of shaping judicatory convictions in criminal proceedings]. Kharkiv: Vyshcha shkola. (in Russian)

11. The Constitution of Ukraine (June 28, 1996), Vidomosti Verkhovnoi Rady Ukrainy [The Official Bulletin of the Verkhovna Rada of Ukraine], 1996, No 30, Art. 141 (as amended by the Law of Ukraine "On Amendments to the Constitution of Ukraine (concerning justice)"(June 2, 2016), Vidomosti Verkhovnoi Rady Ukrainy [The Official Bulletin of the Verkhovna Rada of Ukraine], 2016, No 51, p. 8, Art. 1799), [Online], available at: https://zakon.rada.gov.ua/laws/main/254\%D0\%BA/96-\%D0\%B2\%D1\%80 (in Ukrainian) (accessed 8 January 2020).

12. The Law of Ukraine (Jan. 13, 2011) No. 2939-VI "On Access to Public Information", Vidomosti Verkhovnoi Rady Ukrainy [The Official Bulletin of the Verkhovna Rada of Ukraine], 2011, No 32, Art. 314, [Online], available at: https://zakon.rada.gov.ua/laws/show/2939-17 (in Ukrainian) (accessed 9 January 2020).

13. The Law of Ukraine (Dec. 22, 2005) No. 3262-IV "On Access to Court Decisions", Vidomosti Verkhovnoi Rady Ukrainy [The Official Bulletin of the Verkhovna Rada of Ukraine], 2006, No 15, Art. 128, [Online], available at: https://zakon.rada.gov.ua/laws/show/3262-15 (in Ukrainian) (accessed 9 January 2020).

14. The Law of Ukraine (Jan. 13, 2011) No. 2939-VI "On Access to Public Information", Vidomosti Verkhovnoi Rady Ukrainy [The Official Bulletin of 
the Verkhovna Rada of Ukraine], 2011, No 32, Art. 314, [Online], available at: https://zakon.rada.gov.ua/laws/show/2939-17 (in Ukrainian) (accessed 9 January 2020).

15. The Civil Code of Ukraine (Jan. 16, 2003) No. 435-IV, Vidomosti Verkhovnoi Rady Ukrainy [The Official Bulletin of the Verkhovna Rada of Ukraine], 2003, No. 40-44, Art. 356, [Online], available at: https://zakon.rada.gov.ua/laws/show/435-15 (in Ukrainian) (accessed 9 January 2020).

16. The Civil Procedure Code of Ukraine (Mar. 18, 2004) No. 1618-IV, Vidomosti Verkhovnoi Rady Ukrainy [The Official Bulletin of the Verkhovna Rada of Ukraine], 2004, No. 40-41, No 42, Art. 492, [Online], available at: https://zakon.rada.gov.ua/laws/show/1618-15 (in Ukrainian) (accessed 9 January 2020).

17. The Code of Administrative Procedure of Ukraine (Jul. 6, 2005) No. 2747-IV, Vidomosti Verkhovnoi Rady Ukrainy [The Official Bulletin of the Verkhovna Rada of Ukraine], 2005, No 35-36, No 37, Art. 446, [Online], available at: https://zakon.rada.gov.ua/laws/show/2747-15 (in Ukrainian) (accessed 9 January 2020).

18. The Economic Procedure Code of Ukraine (Nov. 6, 1991) No. 1798-XII, Vidomosti Verkhovnoi Rady Ukrainy [The Official Bulletin of the Verkhovna Rada of Ukraine], 1992, No 6, Art. 56, [Online], available at: https://zakon.rada.gov.ua/laws/show/1798-12 (in Ukrainian) (accessed 9 January 2020).

19. The Criminal Procedure Code of Ukraine (Jul. 7, 2013) No. 4651-VI, Vidomosti Verkhovnoi Rady Ukrainy [The Official Bulletin of the Verkhovna Rada of Ukraine], 2013, No 9-10, 11-12, No.13, Art. 88, [Online], available at: https://zakon.rada.gov.ua/laws/show/4651-17 (in Ukrainian) (accessed 9 January 2020).

20. The Law of Ukraine (Jul.7, 2010) No. 2453-VI "On the Judiciary and the Status of Judges", Vidomosti Verkhovnoi Rady Ukrainy [The Official Bulletin of the Verkhovna Rada of Ukraine], 2016, No 31, Art. 545, [Online], available at: https://zakon.rada.gov.ua/laws/show/1402-19 (in Ukrainian) (accessed 10 January 2020).

21. The Law of Ukraine (Dec. 22, 2005) No. 3262-IV "On Access to Court Decisions", Vidomosti Verkhovnoi Rady Ukrainy [The Official Bulletin of the Verkhovna Rada of Ukraine], 2006, No 15, Art. 128, [Online], available at: https://zakon.rada.gov.ua/laws/show/3262-15 (in Ukrainian) (accessed 9 January 2020).

22. The Judicial Power of Ukraine (2020). Available at: www.court.gov.ua. (accessed 9 January 2020). 
23. The Law of Ukraine (Dec. 22, 2005) No. 3262-IV “On Access to Court Decisions", Vidomosti Verkhovnoi Rady Ukrainy [The Official Bulletin of the Verkhovna Rada of Ukraine], 2006, No 15, Art. 128, [Online], available at: https://zakon.rada.gov.ua/laws/show/3262-15 (in Ukrainian) (accessed 9 January 2020).

24. Recommendation NR (2003) 13 of the Committee of Ministers to Member States, (Jul. 10, 2003) "On the provision of information through the media in relation to criminal proceedings", [Online], available at: https://zakon.rada.gov.ua/laws/show/994_870 (in Ukrainian) (accessed 10 January 2020).

25. The Law of Ukraine (Jul. 7, 2010) No. 2453-VI "On the Judiciary and the Status of Judges", Vidomosti Verkhovnoi Rady Ukrainy [The Official Bulletin of the Verkhovna Rada of Ukraine], 2016, No 31, Art. 545, [Online], available at: https://zakon.rada.gov.ua/laws/show/1402-19 (in Ukrainian) (accessed 10 January 2020).

26. Moskvych L.M., Ivanytskyi S.O., Rusanova T.O. (2009) Pravovyi status nosiiv sudovoi vlady v Ukraini (profesiini suddi, narodni zasidateli, sud prysiazhnykh) [The legal status of judicial authorities in Ukraine (professional judges, people's assessors, jury). In Marochkin I.Ye. (ed.). Kharkiv: Finy (in Ukrainian).

\section{Information abou the author:} Vitalina Novoselova, Chief specialist of the Zaporizhzhia Court of Appeal 10/8, Verkhnia str., Zaporizhzhia, 69032, Ukraine ORCID ID: orcid.org/0000-0003-3347-0837 